\title{
Histone Deacetylase 3 Is Required for Efficient T Cell Development
}

\author{
Kristy R. Stengel, ${ }^{\text {a }}$ Yue Zhao, ${ }^{\text {a }}$ Nicholas J. Klus, ${ }^{\text {b }}$ Jonathan F. Kaiser, ${ }^{\text {a }}$ Laura E. Gordy, ${ }^{\text {c }}$ Sebastian Joyce, ${ }^{\text {c,e }}$ Scott W. Hiebert, ${ }^{\text {a,d }}$ \\ Alyssa R. Summers ${ }^{b}$ \\ Department of Biochemistry, Vanderbilt University School of Medicine, Nashville, Tennessee, USA ; Department of Biology, The University of the South: Sewanee, \\ Sewanee, Tennessee, USA ; Department of Pathology, Microbiology and Immunology, Vanderbilt University School of Medicine, Nashville, Tennessee, USA ; Vanderbilt- \\ Ingram Cancer Center, Vanderbilt University School of Medicine, Nashville, Tennessee, USA'; Veterans Administration Tennessee Valley Healthcare System, Nashville, \\ Tennessee, USA
}

\begin{abstract}
Hdac3 is a key target for Hdac inhibitors that are efficacious in cutaneous T cell lymphoma. Moreover, the regulation of chromatin structure is critical as thymocytes transition from an immature cell with open chromatin to a mature $\mathrm{T}$ cell with tightly condensed chromatin. To define the phenotypes controlled by Hdac3 during T cell development, we conditionally deleted Hdac3 using the Lck-Cre transgene. This strategy inactivated Hdac3 in the double-negative stages of thymocyte development and caused a significant impairment at the CD8 immature single-positive (ISP) stage and the CD4/CD8 double-positive stage, with few mature $\mathrm{CD}^{+}$or $\mathrm{CD8}^{+}$single-positive cells being produced. When $\mathrm{Hdac} 3^{-/-}$mice were crossed with $\mathrm{Bcl}-\mathrm{xL}$-, $\mathrm{Bcl} 2-$-, or $\mathrm{TCR} \beta$-expressing transgenic mice, a modest level of complementation was found. However, when the null mice were crossed with mice expressing a fully rearranged T cell receptor $\alpha \beta$ transgene, normal levels of CD4 single-positive cells were produced. Thus, $\mathrm{Hdac} 3$ is required for the efficient transit from double-negative stage 4 through positive selection.
\end{abstract}

$H^{i}$ istone deacetylases (HDACs) are a heterogeneous group of 18 mammalian enzymes that remove acyl groups from the side chain of lysine (1). The class I enzymes (HDAC1, -2, -3, and -8) are homologous to the Saccharomyces cerevisiae yeast Rpd3 and target multiple lysine residues in the $\mathrm{N}$-terminal tails of histone $\mathrm{H} 3$ and $\mathrm{H} 4$ as well as deacetylate nonhistone targets. These enzymes act in concert with a corepressor $(\mathrm{mSin} 3 \mathrm{~A}$ or $\mathrm{mSin} 3 \mathrm{~B}$ for $\mathrm{HDAC} 1$ and HDAC2, NCOR1 or NCOR2 for HDAC3) that stimulates their activity (2-5). Inositol phosphates are key cofactors of HDACs 1 to 3 that bridge the deacetylase and the corepressor to allow regulation by inositol phosphate signaling and sensing of the metabolic state of the cell $(6,7)$. Several of the class II HDACs are poor deacetylases on histone substrates, but HDAC4, HDAC5, and HDAC7 can recruit HDAC3 to deacetylate targets (8-10). The class III enzymes are sirtuins 1 to 7 and are homologues of the yeast Sir2. These are $\mathrm{NAD}^{+}$-dependent enzymes that sense changes in NAD levels to respond to changes in cellular metabolism (11-13). HDAC11 is the only member of the 4th class of deacetylase and modulates immunity $(14,15)$.

These enzymes have been the target of wide-ranging searches for small molecules that can rewrite the epigenetic code for use in numerous diseases, including neurological diseases, inflammatory disorders, and cancer (1). Broad-spectrum HDAC inhibitors (vorinostat and rhomidepsin) have gained FDA approval for their effectiveness against cutaneous T cell lymphoma (16). These small molecules inhibit multiple class 1 and/or class 2 HDACs but have serious side effects, which has stimulated the development of more selective inhibitors (17). A key to the development of better drugs is the identification of the HDAC(s) that mediates the action of the approved compounds as well as the HDAC(s) responsible for the side effects.

Genetic approaches are being applied to dissect the physiological roles of individual HDACs in tissues that are affected by these drugs and are changing the way that we view individual HDACs. For example, while Hdac1 and Hdac2 can heterodimerize and substitute for one another, deletion of $H d a c 1$ was embryonic lethal at embryonic day 9.5, whereas $H d a c 2^{-1-}$ mice showed cardiac defects shortly after birth (18-20). Heart-specific double deletion of $H$ dacl/2 caused more dramatic cardiac phenotypes, including arrhythmia and severe ventricular dilation (18). Hematopoiesis is another key target tissue, as HDAC inhibitors not only act in T cell lymphoma but also show promise in myeloid leukemia and B cell lymphoma. While germ line deletion of Hdac3 caused early embryonic lethality $(21,22)$, hematopoietic stem cell deletion of Hdac 3 caused a dramatic loss of B cells and T cells and defects in stem cell self-renewal. The stem cell defect appeared to be due to defects in DNA replication, while the loss of lymphopoiesis was traced to a loss of the lymphoid-primed multipotent progenitor cells (LMPPs) (23). In contrast, double deletion of Hdacl and Hdac2 in hematopoietic stem cells caused megakaryocyte apoptosis and thrombocytopenia, which are also observed in patients treated with HDAC inhibitors $(19,20,24)$.

Developing T cells are an ideal model system in which to dissect the roles of individual HDACs in normal physiology. Stepwise removal of the 4 alleles of $\mathrm{Hdac1}$ and $\mathrm{Hdac} 2$ in thymocytes yielded a gradient of Hdac activity, and removal of all four alleles caused a block in early thymic development at double-negative stage 3 (DN3) $(25,26)$. However, as the amount of Hdac1/2 activity decreased, the mice developed $\mathrm{T}$ cell lymphomas, with a particularly high incidence being noted in $\mathrm{Hdacl}^{-/-} / \mathrm{Hdac}^{+/-}$mice. In contrast, the double-knockout mice did not develop tumors, indicating that a low level of $\mathrm{Hdac1} / 2$ activity is required for tumorigenesis. In addition, the tumors that developed in $\mathrm{Hdacl}^{-/-} / \mathrm{Hdac}^{+/-}$mice re-

Received 16 July 2015 Accepted 19 August 2015

Accepted manuscript posted online 31 August 2015

Citation Stengel KR, Zhao Y, Klus NJ, Kaiser JF, Gordy LE, Joyce S, Hiebert SW,

Summers AR. 2015. Histone deacetylase 3 is required for efficient T cell development. Mol Cell Biol 35:3854-3865. doi:10.1128/MCB.00706-15.

Address correspondence to Scott W. Hiebert, scott.hiebert@vanderbilt.edu, or Alyssa R. Summers, arsummer@sewanee.edu.

Copyright @ 2015, American Society for Microbiology. All Rights Reserved. 
mained sensitive to Hdac inhibitors, providing a genetic rationale for the use of these compounds in a synthetic lethal strategy (25, 26).

Here, we have examined the physiological roles of Hdac 3 by deletion of this gene during early thymocyte development using Lck-Cre. Analysis of the developmental markers CD4 and CD8 showed impaired maturation of double-negative cells, an increase in immature single-positive (ISP) $\mathrm{CD}^{+}$cells, and impaired maturation of double-positive (DP) cells, causing a dramatic decrease in single-positive (SP) $\mathrm{CD}^{+}$and $\mathrm{CD} 8^{+}$cells. Gene expression analysis pinpointed $\mathrm{T}$ cell receptor (TCR) signaling to be a possible mechanism and transgenic mouse expression of a combined $T C R \alpha \beta$ transgene to provide a high level of complementation of thymocyte development.

\section{MATERIALS AND METHODS}

Mouse strains. Mice were maintained following Vanderbilt University Medical Center guidelines and in accordance with an Institutional Animal Care and Use Committee-approved protocol. All mice analyzed were between 3 and 6 weeks of age unless otherwise noted. All experimental strains were in a C57BL/6 mouse genetic background. ROSA26-Lox-StopLox-GFP, p56 $6^{l c k}$ proximal promoter Cre (Lck-Cre), OT-II, TCRß, Bcl2, and $B c l-x L$ mice were obtained from The Jackson Laboratory, while conditional Hdac3-knockout mice were generated in the lab of S. W. Hiebert (21).

Flow cytometry. Single-cell suspensions were formed from thymus tissue that had been passed through a $70-\mu \mathrm{m}$-pore-size filter with ice-cold phosphate-buffered saline (PBS). Red blood cells were subsequently lysed with erythrocyte lysis buffer (buffer EL; Qiagen). Cells were then stained with fluorescence-labeled antibodies for $30 \mathrm{~min}$ in PBS containing 0.5\% fetal bovine serum (FBS) at $4^{\circ} \mathrm{C}$. All thymocytes were first gated through green fluorescent protein (GFP) to select for cells expressing Cre and then evaluated using lineage markers, as indicated below. Fluorochrome-conjugated antibodies to the following were used: from eBioscience, antibodies to CD4 (RM4-5 antibody), CD8 (53-6.7 antibody), CD44 (IM7 antibody), CD25 (PC61.5 antibody), TCR $\beta$ (H57-597 antibody), CD147 (RL73 antibody), CD5 (53-7.3 antibody), and CD69 (H1.2F3 antibody), and from BD Biosciences, antibody to CD3 (145-2C11 antibody). Analysis was performed with a 3-laser BD LSRII or BD Fortessa flow cytometer. The acquired data were analyzed using FlowJo software (TreeStar).

Microarray and real-time quantitative PCR. Thymocyte single-cell suspensions were sorted with a BD FACSAria cell sorter, with the first gating being on GFP-positive cells and then anti-CD4 and anti-CD8 markers being used to identify double-positive cells. Total RNA was purified from the sorted thymocytes with a PerfectPure RNA extraction kit (5 Prime, Inc., Gaithersburg, MD). RNA was pooled from 2 wild-type (WT) and $2 \mathrm{Hdac}^{-1-}$ animals for a total of 3 biological replicates from 6 mice each. RNA was prepared and hybridized to an Affymetrix GeneChip mouse gene 1.0 ST array for analysis in the Vanderbilt Functional Genomics Shared Resource. Data were analyzed using GeneSpring (Agilent Technologies) and Panther classification system software. Gene ontology analyses of the microarray data were performed using the web-based tool kit WebGeStalt. $P$ values were calculated using a hypergeometric test (raw $P$ values) and adjusted by multiple testing (adjusted $P$ values). Enriched categories identified using different databases are presented in the figures. Quantitative reverse transcription-PCR (qRT-PCR) was performed using Sybr green and real-time PCR.

Western blot analysis. Where noted, thymocytes were sorted by GFP status prior to lysis in radioimmunoprecipitation assay (RIPA) buffer containing protease inhibitors. Cleared lysates were resolved by SDSPAGE. Specific proteins were detected with the antibodies to the following: from Cell Signaling Technology, phosphorylated extracellular signalregulated kinases (ERKs) 1 and 2 with a Thr residue at position 202 and Tyr residue at position 204, extracellular signal-regulated kinases 1 and 2, histone $\mathrm{H} 3$, and histone $\mathrm{H} 4$; from Abcam, Hdac3, histone $\mathrm{H} 3$ with a trimethylated lysine 9 (H3K9me3), histone 4 with an acetylated lysine 12 (H4K12ac), H4K5ac, and tubulin; and from Upstate Biotechnology, $\mathrm{H} 3 \mathrm{~K} 9 \mathrm{ac}$ and H4K16ac.

T cell activation assay. Thymocytes were isolated from WT and $\mathrm{Hdac}^{-1-}$ mice, resuspended in $5 \mathrm{ml}$ PBS containing $0.5 \%$ fetal bovine serum, and rested on ice for $1 \mathrm{~h}$. The cells were then filtered through a $70-\mu \mathrm{m}$-pore-size cell strainer and resuspended in ice-cold PBS at a density of $5 \times 10^{6}$ cells per ml. Cells were stimulated with anti-mouse CD3 antibody $(10 \mu \mathrm{g} / \mathrm{ml})$ that had been pre-cross-linked with goat anti-hamster immunoglobulin antibody $(10 \mu \mathrm{g} / \mathrm{ml})$ for $2,5,20$, and $45 \mathrm{~min}$ at $37^{\circ} \mathrm{C}$. Untreated cells served as controls. Cells were collected by centrifugation, and whole-cell lysates were made using RIPA buffer containing protease and phosphatase inhibitors prior to Western blotting.

RNA-Seq analysis. Single-cell thymocyte suspensions were sorted for DP stage 1 (DP1; GFP positive $\left.\left[\mathrm{GFP}^{+}\right] \mathrm{CD}^{+} \mathrm{CD}^{+} \mathrm{CD} 5^{\text {lo }} \mathrm{TCR} \beta^{\text {lo }}\right)$ and DP2 $\left(\mathrm{GFP}^{+} \mathrm{CD} 4^{+} \mathrm{CD} 8^{+} \mathrm{CD} 5^{\text {hi }}\right.$ TCR $\beta$-intermediate $\left.\left[\mathrm{TCR} \beta^{\text {int }}\right]\right)$ populations. Total RNA was extracted with the TRIzol reagent (Ambion) and provided to the Vanderbilt Vantage Core Shared Resource for library construction and sequencing. Briefly, samples were depleted of rRNA using a RiboGone mammalian rRNA removal kit (Clontech). Libraries were created with a SMARTer stranded mRNA deep-sequencing (RNASeq) kit (Clontech) and sequenced with an Illumina HiSeq 2500 sequencer on an SR-50 apparatus run using a Rapid (v2) kit (Illumina) and aiming for 28 million reads per sample. Preprocessed reads were aligned to the mouse transcriptome (version mm10; downloaded from the UCSC Genome Browser) using the TopHat program, and differential gene expression was determined using the Cuffdiff program as previously described (27).

Accession number. The gene expression data for these studies can be found under GEO accession number GSE72917.

\section{RESULTS}

Hdac3 is essential for efficient development of functional $T$ cells. To examine the role of Hdac 3 in $\mathrm{T}$ cell development, we crossed our Hdac3 floxed mice with Lck-Cre transgenic mice. The Lck promoter is expressed during the double-negative stages of $\mathrm{T}$ cell development, such that Hdac3 is inactivated relatively early in thymocyte development. We additionally crossed our mice with ROSA26-Lox-Stop-Lox-GFP transgenic mice to assess the Cre-mediated recombination efficiency in our model (28), such that green fluorescent protein-positive $\left(\mathrm{GFP}^{+}\right)$cells expressed Cre and thus simultaneously had an Hdac3 deletion. This approach allowed us the additional control of assessing GFP-negative $\left(\mathrm{GFP}^{-}\right)$ cells and $\mathrm{GFP}^{+}$cells with the Hdac3 deletion in the same mouse. $\mathrm{Hdac} 3$ inactivation was variable, as detected using fluorescenceactivated cell sorting (FACS) for GFP status (Fig. 1A), and the levels of GFP closely correlated with the level of Hdac3 inactivation, as determined by Western blot analysis (Fig. 1B). Sorted $\mathrm{GFP}^{+}$cells showed that the loss of Hdac3 resulted in global changes in the levels of histone acetylation by Western blot analysis, including increased levels of $\mathrm{H} 4 \mathrm{~K} 5, \mathrm{H} 4 \mathrm{~K} 12$, and $\mathrm{H} 4 \mathrm{~K} 16$ acetylation (Fig. 1C). Assessment of $\mathrm{Lck}-\mathrm{Hdac}^{-1-}$ mice with $85 \%$ or more $\mathrm{GFP}^{+}$thymocytes showed normal numbers of thymocytes (Fig. 1D and E) and a normal thymus architecture (data not shown).

Next, we used flow cytometry with anti-CD4 and anti-CD8 to assess thymocyte development into the two major classes of $\mathrm{T}$ cells. Hdac3-null thymocytes appeared to accumulate at the CD4/ CD8 double-positive stage, with decreased progression to singlepositive $\mathrm{CD}^{+}$and $\mathrm{CD}^{+}$cells. The loss of $\mathrm{CD} 4^{+}$cells was the most dramatic, with $80 \%$ of $\mathrm{CD} 4^{+}$cells being lost, while $\mathrm{CD} 8^{+}$ cells were reduced by about 40 to $60 \%$ (Fig. 1D and data not 


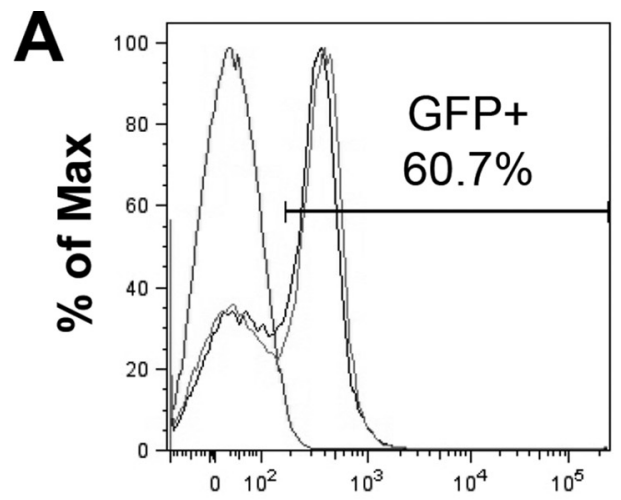

B

$+/+\quad+/+$ F/- F/- Hdac3

$-++\quad+$ Cre

$\begin{array}{llll}0.0 & 55.8 \quad 29.8 \quad 58.0 & \%\end{array}$

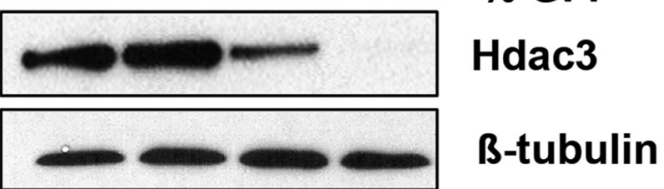

C WT Hac3 $^{-/-}$

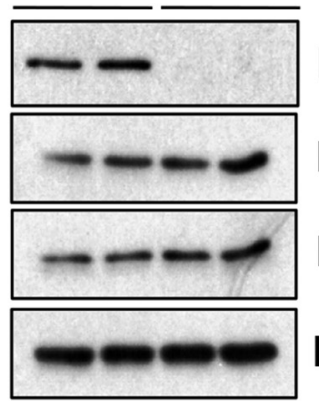

Hdac3

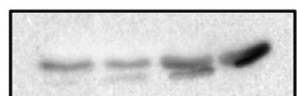

H4K16ac
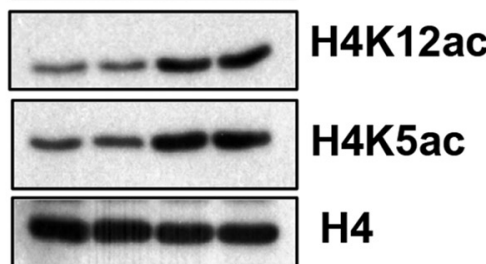

D
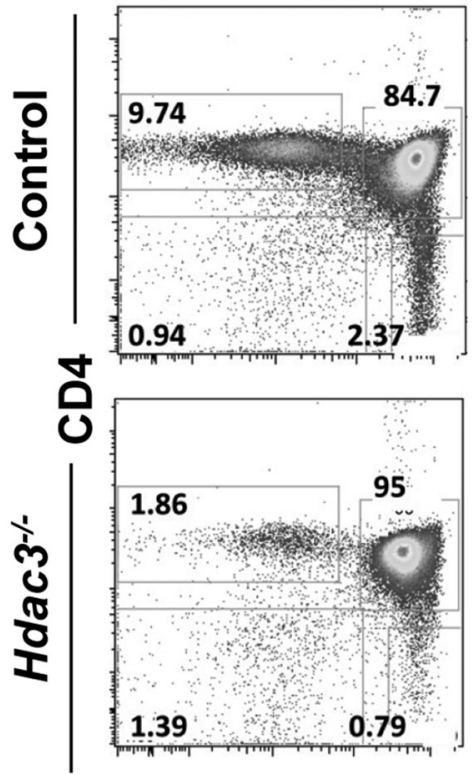

CD8

E

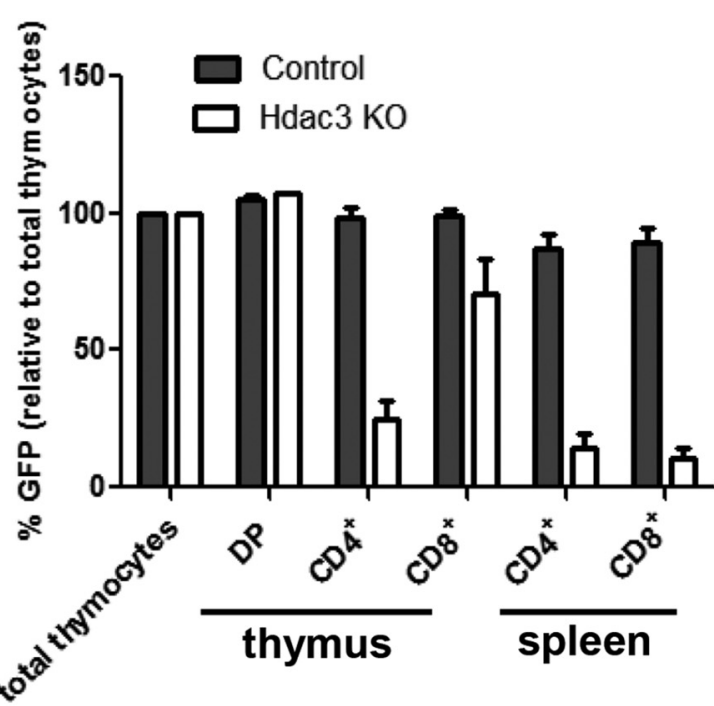

$\mathbf{F}$

Thy
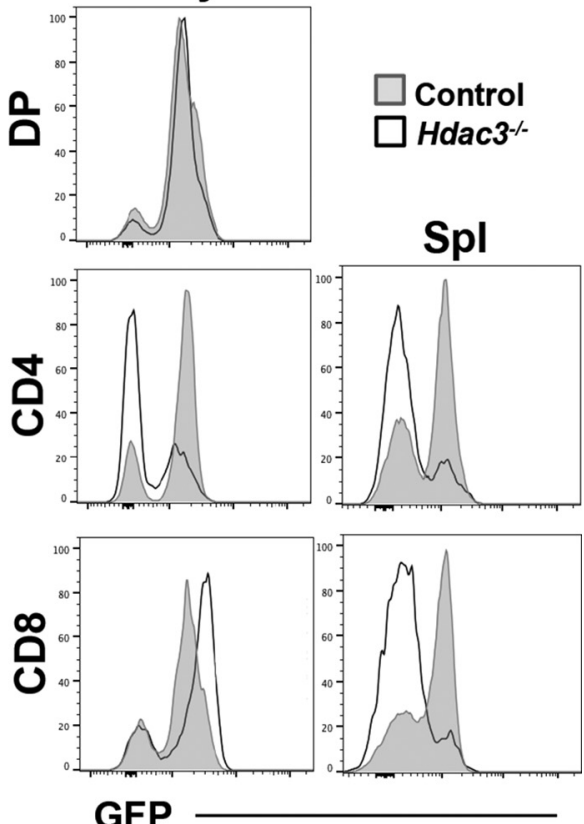
shown). Consistent with the majority of thymocytes accumulating at the DP stage of development, FACS analysis of splenocytes showed a dramatic reduction in the number of $\mathrm{T}$ cells that were $\mathrm{GFP}^{+}$and either $\mathrm{CD}^{+}$or $\mathrm{CD}^{+}$(Fig. $1 \mathrm{E}$ and $\mathrm{F}$ ), which is consistent with the effects observed on inducible NK T cells after $C D 4^{-}$ Cre-mediated deletion of Hdac3 (29). While there were fewer $\mathrm{Hdac}^{-/-} \mathrm{T}$ cells in the spleen, the architecture of the spleen in Lck-Hdac3 ${ }^{-1-}$ mice was relatively normal (data not shown), which was likely due to the preponderance of cells that escaped Cre-mediated Hdac3 deletion and were wild type, indicating that $\mathrm{Hdac} 3$ is required for efficient $\mathrm{T}$ cell development.

Lck-Cre-dependent cleavage is typically thought to occur in CD4/CD8 double-negative stage $2\left(\mathrm{DN} 2 ; \mathrm{CD} 25^{+} / \mathrm{CD} 44^{+}\right)$to double-negative stage 4 (DN4; CD $25^{-} / \mathrm{CD} 44^{-}$), and small numbers of $\mathrm{GFP}^{+}$cells were first detected in DN2, but they continued to accumulate through DN3 $\left(\mathrm{CD} 25^{-} / \mathrm{CD} 44^{+}\right)$and into DN4 (data not shown) $(30,31)$. When we gated on $\mathrm{GFP}^{+}$cells, we noted $50 \%$ more CD $25^{+}$cells compared to the number in the controls (Fig. 2A). TCR $\beta$ expression commences from DN3 (3134 ), and when the DN3 and DN4 populations of $\mathrm{GFP}^{+}$cells were permeabilized prior to further stratification using intracellular expression of TCR $\beta$, roughly a third of the $\mathrm{Hdac3}^{-1-}$ DN4 cells lacked expression of TCR $\beta$ (Fig. 2B), suggesting a defect in the transition from DN4 to the double-positive stage.

The accumulation of CD8 single-positive cells in the thymus (Fig. 1E and F) but a lack of CD8 single-positive cells in the spleen (Fig. 1E and F) suggested that the $\mathrm{CD} 8^{+}$thymocytes were immature cells that were inefficiently moving toward the double-positive stages. Therefore, we used cell surface expression of CD147 and $\mathrm{CD} 3$ to enumerate immature $\mathrm{CD} 8^{+}$cells. In $\mathrm{Hdac} 3^{-1-}$ mice, there was a 2- to 4 -fold increase $\mathrm{CD} 8^{+} \mathrm{CD} 147^{+} \mathrm{CD} 3^{-}$immature single-positive (ISP) thymocytes (Fig. 2C), indicating impaired development from DN4 cells through the CD8 single-positive stage prior to the CD4/CD8 double-positive stage.

The loss of Hdac3 affects gene expression. Given the links between Hdac3 function and transcriptional control and the apparent block of thymocyte maturation at the CD4/CD8 doublepositive stage, we analyzed global gene expression of FACS GFP ${ }^{+}$ $\mathrm{CD}^{+} \mathrm{CD}^{+}$thymocytes to further probe how the loss of Hdac3 might affect development. Microarray analysis showed augmented expression of genes involved in T cell differentiation, but many of these genes were turned off rather than induced by the loss of Hdac3. Indeed, the number of genes showing a loss of expression outnumbered the number of genes showing an induction of expression by nearly 2 to 1 . A group of critical regulatory genes normally induced upon positive selection (Id2, Id3, Myc, Egr1, and Egr2) (35), as well as genes required for T cell functions (e.g., Gfi1) and cell cycle progression, was downregulated in Hdac3-null DP cells (Fig. 3A). The downregulation of $M y c$, a target of TCR sig- naling that controls metabolism, and many genes that contribute to cell cycle control, such as E2F5 and cyclin D2 (Fig. 3B), suggested that these cells were less robust than control cells. There was also the deregulation of several key transcriptional regulators, including $I d 2$ and $I d 3$, as noted above (which would allow unfettered E-protein functions), Gfi1, Lmo4, and the Ikaros family member Helios (Ikzf2), all of which could disrupt T cell development (36).

Additionally, there was a decrease in the levels of expression of genes normally upregulated in the CD4 lineage. Perhaps most importantly for cells in the early DP stages of T cell development, when positive selection is set to begin or is taking place, there were numerous signaling genes affected by the loss of Hdac3 (Fig. 3A and B). Interleukin-7 (IL-7) is a key cytokine for lymphoid proliferation $(37,38)$, and the level of expression of the gene for its receptor (IL7ra) was 2.3-fold lower in the Hdac3-deficient thymocytes (Fig. 3A). Likewise, the level of expression of Jak2 was 1.5fold lower and that of CD44 was 1.6-fold lower in the absence of Hdac3 (Fig. 3A). Conversely, the dual-specificity phosphatase Dusp5, as well as Vav3 and Il2ra (CD25), was upregulated (Fig. $3 \mathrm{~A})$. Dusp5 is a negative regulator of ERK signaling that was recently found to be suppressed by class 1 HDACs in muscle cells (39). The level of Dusp5 mRNA was roughly 2- to 3-fold higher in Hdac $3^{-1-}$ thymocytes in both microarray and qRT-PCR analyses, but Dusp5 protein levels were only modestly affected (data not shown).

Hdac 3 is required for efficient positive selection. The amount of CD25 was higher in the double-negative stage 3 (DN3) population (Fig. 2), and the amount of CD25 was higher at the mRNA level in double-positive cells (Fig. 3A). Therefore, we used flow cytometry to further scrutinize the CD4/CD8 double-positive thymocytes in $\mathrm{Hdac}^{-1-}$ mice. As predicted by the mRNA expression analysis, $\mathrm{Hdac}^{-1-}$ double-positive cells expressed higher levels of CD25 on the cell surface (Fig. 4A). While we noted a significant population of CD4/CD8 double-negative cells lacking the intracellular expression of TCR $\beta$ (Fig. 2), the majority of DP cells expressed somewhat more TCR $\beta$ on the cell surface, although there was a reduction in the small number of cells expressing the highest levels of TCR $\beta$ (Fig. 4A). Likewise, CD3 was expressed at significantly higher levels in the Hdac3-deficient thymocytes (Fig. 4A), but there was a reduction in the number of $\mathrm{CD} 3{ }^{\text {hi }}$ thymocytes (Fig. 4A) $(40,41)$.

Given the lack of the CD $3^{\text {hi }}$ and TCR $\beta^{\text {hi }}$ populations, we used cell surface expression of CD5 and CD69 versus that of TCR $\beta$ to examine the maturation of double-positive cells. In $\mathrm{Hdac3}^{-1-}$ thymocytes there was a skewing toward CD $5^{\text {hi }}$ TCR $\beta^{\text {int }}$ and significantly fewer CD $5^{\text {low }}$ TCR $\beta^{\text {low }}$ cells in the null mice (doublepositive stage 1 [DP1]) (Fig. 4B). Further, in addition to a reduction in DP1 cell numbers, the median level of CD5 expression was

FIG 1 Loss of Hdac3 affects histone acetylation and thymocyte development. (A) FACS analysis of thymocytes from control mice (no GFP expression) and $L c k-H d a c 3^{-1-}$ mice $\left(\mathrm{GFP}^{+}\right)$. Shown is a tracing for a control mouse that lacks GFP expression and two Lck-Hdac $3^{\text {flox/- }}$ mice in that $60 \%$ of the thymocytes are $\mathrm{GFP}^{+}$and thus have the Hdac3 deletion. (B) Western blot of Hdac3 expression in total thymocytes with various degrees of GFP expression. Hdac3 knockout is variable, as indicated by GFP expression. $+/+, L c k-H d a c 3^{+/+}$mice; F/, Lck-Hdac $3^{\text {flox } /-}$ mice. (C) Western blot of histone modification on thymocytes of either WT-Lck-Hdac $3^{+/+}$or Lck-Hdac flox $^{\text {fl- }}$ mice sorted using GFP expression. (D) FACS analysis using anti-CD4 and anti-CD8. Unless otherwise noted, plots are representative of those for at least 5 mice. The numbers indicate the percentages of cells analyzed. (E) Bar graphs showing the percentage of GFP-positive T cells from thymic and splenic subpopulations in control or $\mathrm{Hdac} 3^{-1-}$ mice. Student's $t$ test was used to evaluate each pair, and the differences in CD $4^{+}$and $\mathrm{CD} 8^{+}$cells from the spleen were significant $(P<0.05)$, whereas only the difference for $\mathrm{CD}^{+}$cells from the thymus were statistically significant at this level. KO, knockout. (F) FACS analysis of T cells containing CD4 and CD8 versus GFP from the thymus (Thy) and spleen (Spl) showing that Hdac3 ${ }^{-/-}$thymocytes do not persist in the spleen. Plots are representative of those from analyses of at least 5 mice. 
A

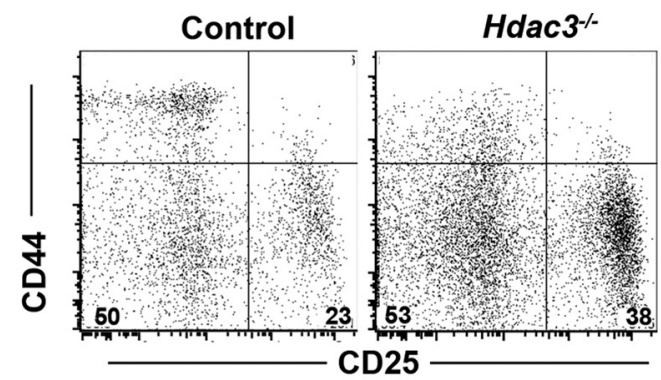

B
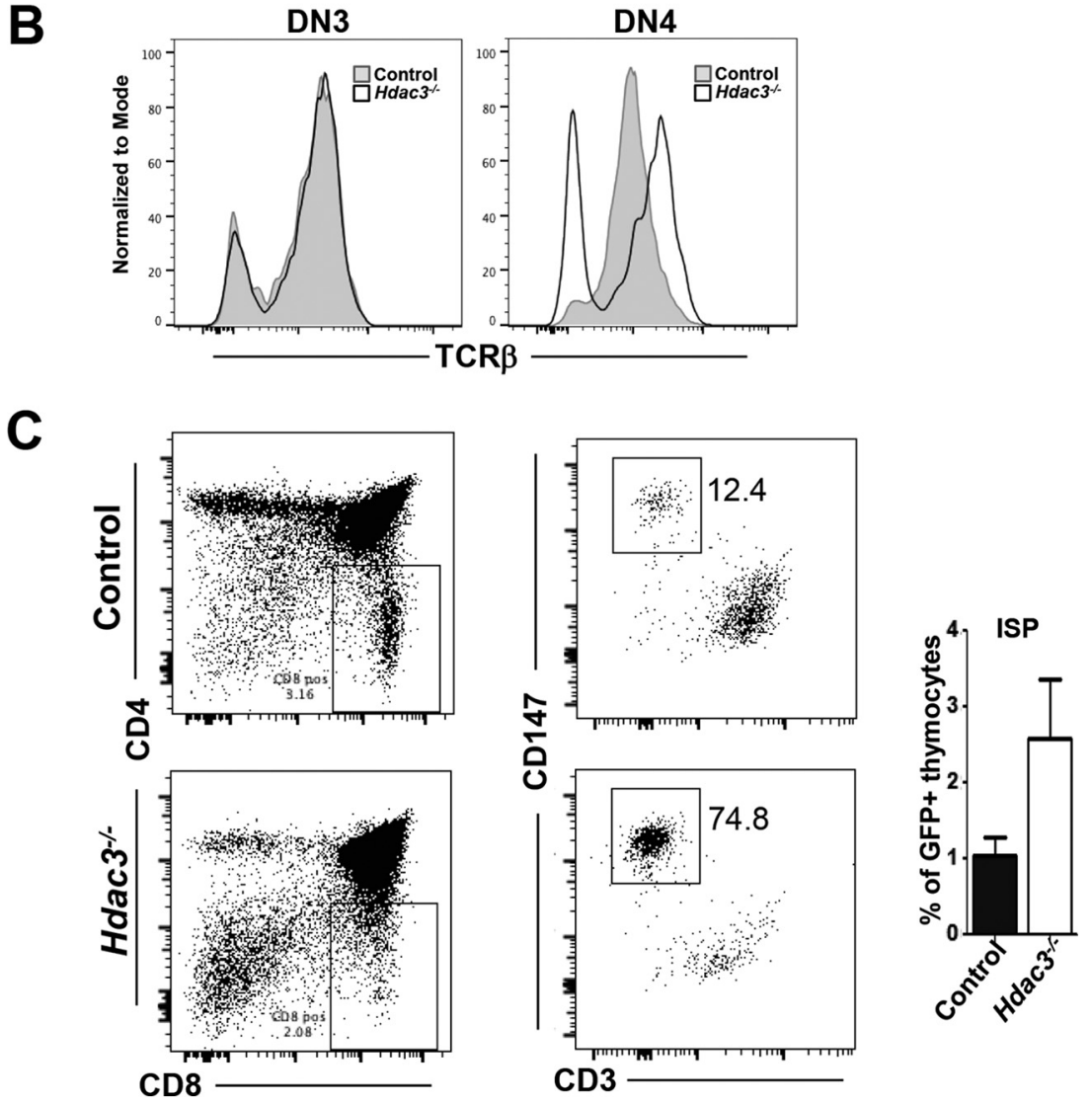

FIG 2 Hdac3 is required for progression through early thymocyte development. (A) FACS analysis of $\mathrm{GFP}^{+}$double-negative $\left(\mathrm{CD} 4^{-} / \mathrm{CD} 8^{-}\right.$) thymocytes using CD44 and CD25 to delineate DN1 to DN4. The numbers in the lower corners of the gates indicate the percentages of cells analyzed. (B) FACS analysis of intracellular TCR $\beta$ expression by DN3 and DN4 cells. (C) (Left) FACS analysis of total thymocytes using CD4 and CD8 markers, with the results for CD ${ }^{+}$cells being replotted using CD147 and CD3 expression. (Right) Bar graph presenting the composite results for 6 mice.

noticeably higher in the $H d a c 3^{-1-} \mathrm{DP} 1$ population. At the same time, there was a drop in the number of CD $5^{\text {hi }} \mathrm{TCR}^{\mathrm{Hi}}(\mathrm{DP} 3)$ cells in the $H \mathrm{Hac}^{-1-}$ mice, suggesting that these cells were impaired in their development to DP3 and on to the single-positive stages. Likewise, CD69 is a marker of TCR signaling in cells undergoing positive selection that is subsequently suppressed as thymocytes mature (42), to allow emigration from the thymus (reviewed in reference 43). $\mathrm{Hdac}^{-1-}$ double-positive cells expressing high levels of TCR $\beta$ failed to coexpress CD69 (Fig. 4B, right, arrow), and the cells completing positive selection that were TCR $\beta^{\text {hi }}$ CD69 ${ }^{\text {hi }}$ failed to accumulate in the absence of $H$ dac3 (Fig. 4B), suggesting that Hdac3 contributes to positive selection.

Inactivation of $\mathrm{Hdac} 3$ alters the gene expression program in thymocytes undergoing positive selection. Given the defects that we observed in DP1 and DP2 of thymocyte development, we further subdivided the CD4/CD8 double-positive populations analyzed earlier (Fig. 3) to define how inactivation of Hdac3 affects gene expression. The DP1 and DP2 populations were isolated from wild-type and $\mathrm{Hdac}^{-1-}$ mice and mRNA deep-sequencing (RNA-Seq) analysis was performed. During the transition of wildtype DP1 cells to DP2, just over 600 genes were induced, while nearly 3 times this number were downregulated (35) (Fig. 5A). Central among the induced genes were the gene for the IL-7 receptor (nearly 40-fold increase), which promotes survival (44); the genes for CD69 (14-fold) and CD53 (40-fold); as well as Bcl2 (6-fold), which also impairs apoptosis to promote survival (45). Further, there was an induction of a transcriptional program that includes key regulators of T cell development, such as the E-pro- 

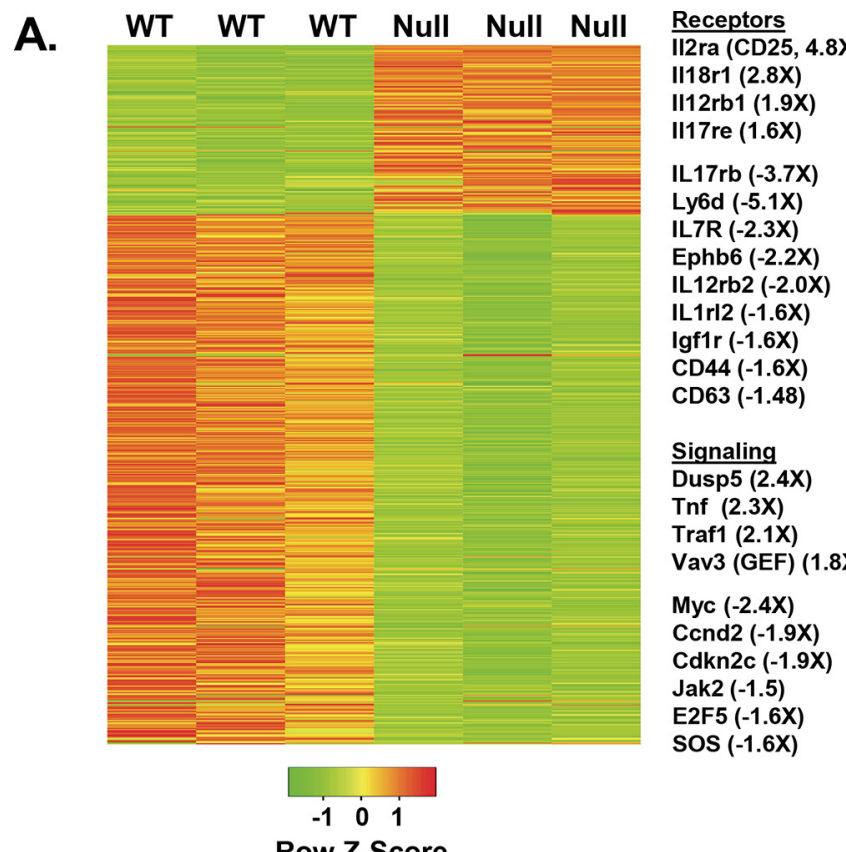

CD63 (-1.48)

\section{Signaling} Dusp5 (2.4X)

Tnf (2.3X)

Vav3 (GEF) (1.8X)

Myc (-2.4X)

Cend2 (-1.9X)

Cdkn2c (-1.9X)

Jak2 (-1.5)

E2F5 (-1.6X)

$\operatorname{sos}(-1.6 \mathrm{X})$

$\begin{array}{lll}-1 & 0 & 1\end{array}$

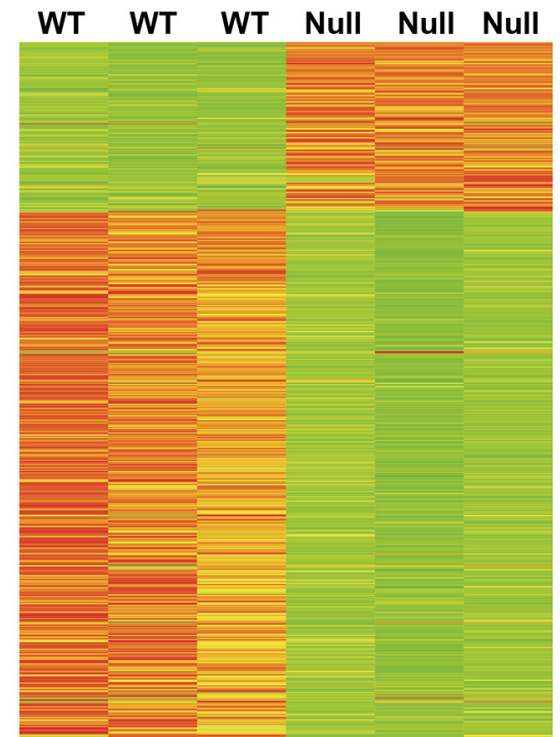

Traf1 (2.1X)

T-cell Selection
Gimap7 (6.7X)
CD53 $(2.6 \mathrm{X})$
CD59a (1.56)
Tbl1x (1.7X)
Tbl1xr1 (1.6X)
Tle6 (1.6X)
Transcription
Stat4 (1.7X)
Tet2(-1.6X)
Egr1 (-1.7X)
Nr4a3 (-1.7X)
Gfi1 (-1.8X)
Erg2 (-1.9X)
Id3 (-1.9X)
Etv6 (-1.9X)
Lmo4 (-2.0X)
Id2 (-2.1X)
Tet1 (-2.2X)
Ikzf2 (-2.3X)

T-cell Selection

CD53 (2.6X)

Tbl1x (1.7X)

Tbl1xr1 (1.6X)

Transcription

Stat4 (1.7X)

Egr1 (-1.7X)

$\mathrm{Nr4a3}(-1.7 \mathrm{X})$

Gfi1 (-1.8X)

Id3 $(-1.9 X)$

Etv6 (-1.9X)

Lmo4 (-2.0X)

Row Z-Score

B.

\section{Category Enrichment}

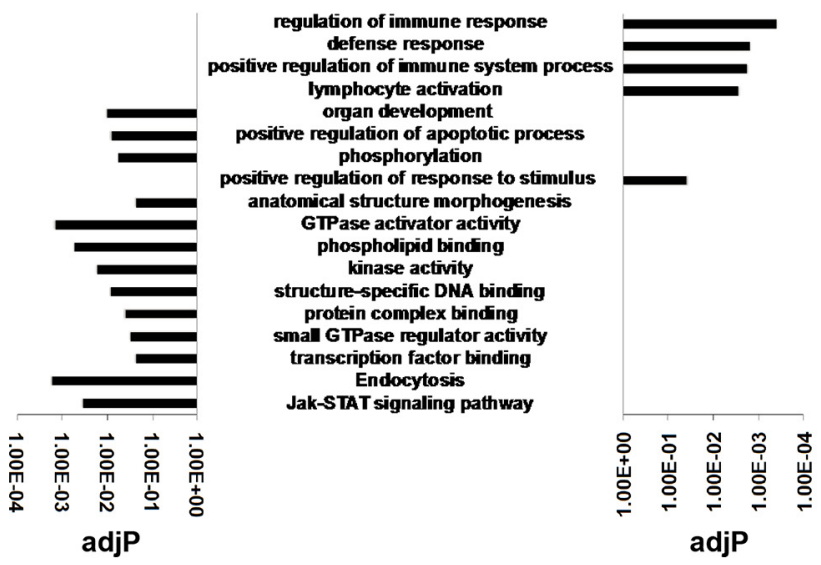

FIG 3 Gene expression analysis of WT and $\mathrm{Hdac}^{-1-}$ (Null) CD4/CD8-positive thymocytes. (A) Heat map showing the $\log _{2}$ values of the relative fluorescence intensity of 1,800 genes affected by the loss of Hdac3. (Right) Gene ontology groupings of genes and the fold change in gene expression. (B) Bar graph showing the pathways affected by the inactivation of $H$ dac3. $P$ values were calculated using a hypergeometric test (raw $P$ value) and adjusted by multiple testing (adjusted $P$ values $[\operatorname{adj} \mathrm{P}])$.

tein inhibitor of differentiation (Id2, 6-fold), Helios (Ikzf2, 4.7fold), the NFKB component RelB (4-fold), the Ets family member Etv5 (4-fold), and the homeodomain protein Hhex (3.7-fold). Conversely, the cell cycle machinery was suppressed in DP2 cells, as the levels of expression of cyclin $E$ (-5.7-fold), cyclin A2 (-3.5fold), cyclin B2 (-4.6-fold), Cdk1 (-3.8-fold), E2F1 (-3.5-fold), E2F2 (-4.6-fold), E2F8 ( -4.7 -fold), and $M y c$ (-2-fold) were all decreased. While the level of expression of Rorc $(R O R \gamma t)$, a key contributor to positive selection (46), decreased, as expected, during this transition (35), the drop was relatively small ( -1.7 -fold). Conversely, Nur77 (Nr4a1) was induced (7.9-fold) and its related family member Norl (Nr4a3) was dramatically induced (35-fold). Induction of these genes is consistent with these nuclear hormone receptor family members being robustly activated by TCR signaling in DN2 cells in preparation for negative selection (47).
When the DP1 cells lacking Hdac3 were compared to wild-type DP1 cells, over 1,000 genes were significantly induced, with some of the largest changes in expression occurring among key transcriptional regulators, such as retinoic acid receptor alpha (Rara, 2.2-fold) and Mef2a, Mef2b, and Mef2c (Fig. 5A). While RORyt (Rorc) contributes to positive selection (46), Rorb was induced nearly 3 -fold, with the expression of Rorc was unchanged. Similar to our prior analysis (Fig. 3), CD25 (Il2ra) was overexpressed in both DP1 and DP2 in Hdac3 ${ }^{-1-}$ thymocytes (Fig. 5B and C). The Hdac ${ }^{-1-}$ DP2 thymocytes also expressed 3.7-fold more Rorb, and while the level of expression of Rorc was higher, it was more in line with this gene not being slightly downregulated during the DP1-to-DP2 transition (1.8-fold). It is also notable that transcription factors and corepressors that recruit Hdac 3 and that autoregulate their own expression, including two genes associated with 

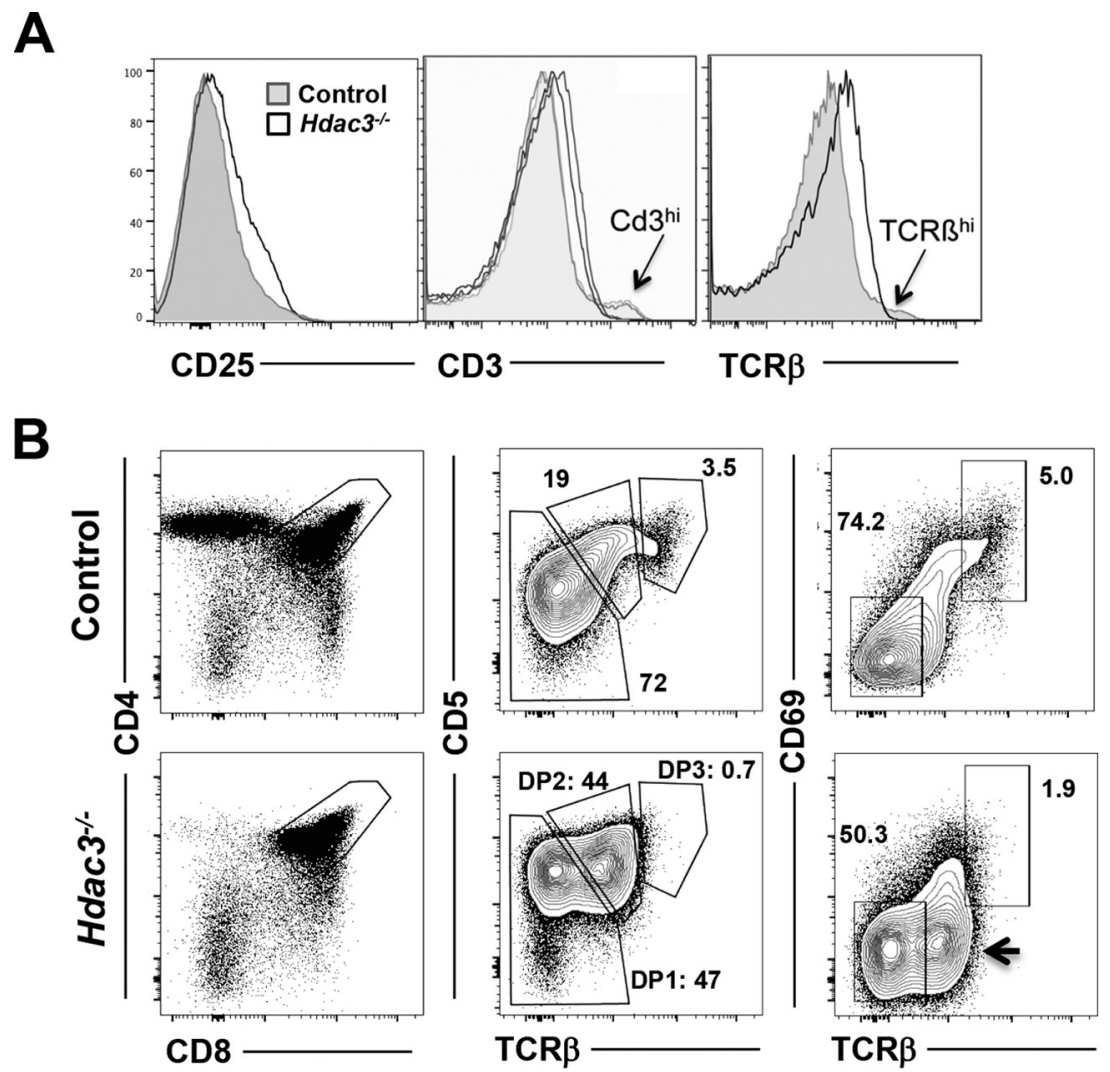

FIG 4 Hdac3 is required for progression through the CD4/CD8 double-positive stages of thymocyte development. (A) FACS analysis of CD4/CD8-positive cells further fractionated by CD25, CD3, and TCR $\beta$ expression. (B) FACS analysis of CD4/CD8-positive cells further fractionated using CD5 or CD69 versus TCR $\beta$ expression. Plots are representative of those from analyses of at least 5 mice. Arrow, TCR $\beta^{\text {hi }} / C D 69^{\text {low }}$ population.

hematopoietic malignancies, Bcl6 (2.4-fold) and Mtg16 (Cbfa2t3, 3.0 -fold) $(48,49)$, were upregulated in the $\mathrm{Hdac}^{-1-}$ DP2 thymocytes. Finally, we noted that multiple histone deacetylases were deregulated, perhaps in an attempt to compensate for the loss of Hdac3, including Hdac1 (1.6-fold), Hdac4 (1.8-fold), Hdac5 (1.8fold), Hdac7 (2.1-fold), and Hdac11 (4.1-fold) (Fig. 5D).

Partial rescue by transgenic mouse expression of $\mathrm{Bcl} 2$ or $\mathrm{Bcl}$ $x \boldsymbol{L}$. When the gene expression of $\mathrm{Hdac}^{-1-}$ DP2 thymocytes was compared to that of control cells, we noted that while the level of expression of $B c l-x L$ (2.1-fold) was slightly higher in the null cells, that of $B c l 2$ was reduced even more (-3.4-fold). This is striking, because during the DP1-to-DP2 transition in wild-type cells, $B c l 2$ (6.4-fold) was induced, while the levels of expression of Bak ( -1.9 -fold), Bad ( -3.5 -fold), and Bid (-3.1-fold), which trigger apoptosis, were reduced to promote survival. Given that positive selection rescues thymocytes from apoptosis or allows death due to neglect, we crossed our $L c k-H d a c 3^{\text {floxfflox }}$ mice to $L c k-B c l-x L$ (50) and $L c k-B c l 2$ (51) transgenic mice. Bcl- $x L$ is a critical mediator of cell survival, as it allows the TCR $\alpha$ locus to undergo multiple rearrangements to produce a functional TCR that can successfully interact with the major histocompatibility complex (MHC) and pass positive selection $(36,50)$. Analysis of our $L c k-H d a c 3^{-1-}$, $B c l-x L$ transgenic mice yielded a significant recovery (57\%) for $\mathrm{CD}^{+}{ }^{+}$cell selection, but $B c l-x L$ expression had less of an effect on $\mathrm{CD} 4^{+}$cells compared to its effect on $\mathrm{CD} 4^{+}$cells in control mice expressing $\mathrm{Bcl}-x \mathrm{~L}$ (Fig. 6). A consistent feature of the $\mathrm{Lck}-\mathrm{Hdac}^{-{ }^{-1}}$, $B c l-x L$ mice was the broadening of the $L c k-H d a c 3^{-1-} / B c l-x L D P$ cell quadrant, suggesting that more of these cells became $\mathrm{CD} 4{ }^{\text {hi }}$ / $\mathrm{CD} 8^{\text {int }}$, which is an intermediate in the progression from DP to CD4 or CD8 single-positive cells. Likewise, there were more $\mathrm{CD} 8^{\mathrm{hi}} / \mathrm{CD} 4^{\text {int }}$ cells, which could imply the increased survival of ISP cells (34) (Fig. 2B). The Lck-Hdac $3^{-1-} / B c l 2$ transgenic mice showed modest improvements in the numbers of $\mathrm{CD}^{+}$thymocytes (Fig. 6), but it was not to the degree observed in control mice expressing $B c l 2$. Thus, transgenic mouse expression of $B c l-x L$ and $B c l 2$ indicated that apoptosis due to neglect only modestly contributed to the impaired maturation of thymocytes in the absence of Hdac3.

Complementation with a functional rearranged TCR. While the DP1 and DP2 Hdac3 $3^{-1-}$ thymocytes expressed CD5 and CD69 (Fig. 4), as well as other genes that are hallmarks of TCR signaling, such as Hras, CD69 expression lagged that of TCR $\beta$ (Fig. 4B, bottom right, arrow). In addition, many signaling-related genes that were induced by the loss of $\mathrm{Hdac} 3$ are negative regulators of signal transduction (e.g., Dusp5, Dusp7) (Fig. 3 and 5C and D). Other key regulatory nodes that suppress signaling pathways were also overexpressed in $\mathrm{Hdac}^{-1-}$ DP1 or DP2 thymocytes, including adenomatous polyposis coli (Apc, 2.1-fold) and GSK3 3 (1.6-fold), which suppress Wnt signaling upstream of $M y c$ (-2.7-fold) (52), which is a key regulator of metabolism and ribosomal genes (53). In addition, the neurofibromatosis 1 (Nf1, 2.0-fold) tumor suppressor, which opposes Ras signaling and phosphatase, and the tensin homolog (Pten, 1.8-fold), which regulates Akt signaling, were overexpressed. Overall, the gene expression analysis sug- 


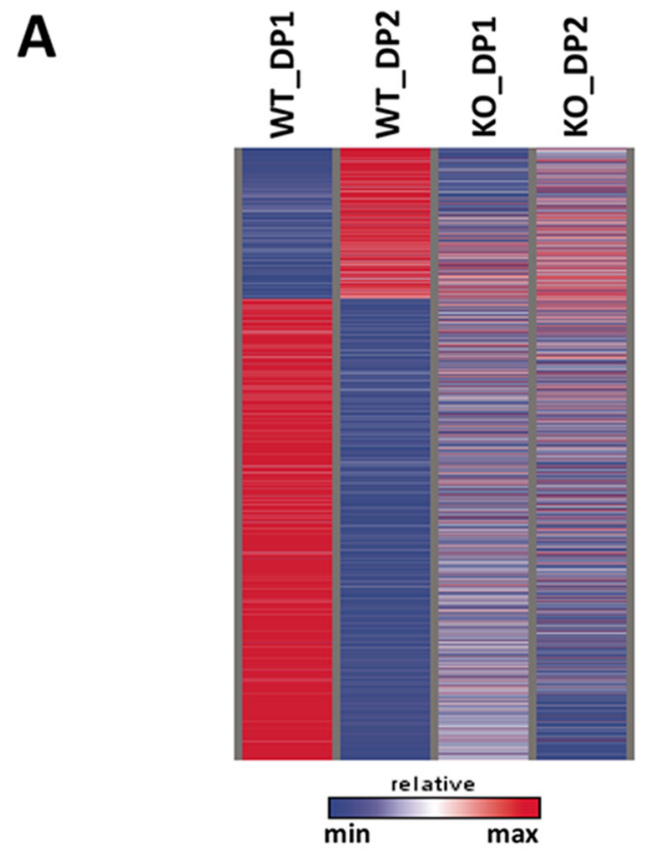

C

\begin{tabular}{|c|c|c|}
\hline \multicolumn{3}{|c|}{ DP1 up-regulated in $\mathrm{Hdac3} \mathrm{KO}$} \\
\hline Category & Gene \# & $\operatorname{adjp}$ \\
\hline TCR signaling pathway & 16 & $6.04 \mathrm{E}-5$ \\
\hline Chemokine signaling pathway & 20 & 0.0002 \\
\hline MAPK signaling pathway & 25 & 0.0002 \\
\hline Regulation of actin cytoskeleton & 21 & 0.0003 \\
\hline Focal adhesion & 19 & 0.0007 \\
\hline \multicolumn{3}{|c|}{ DP1_down-regulated (in Hdac3 KO) } \\
\hline Category & Gene \# & adjp \\
\hline Ribosome & 66 & $4.15 \mathrm{E}-62$ \\
\hline Metabolic Pathways & 170 & $1.61 E-39$ \\
\hline Oxidative Phosphorylation & 53 & 8.67E-33 \\
\hline Proteasome & 24 & 2.73E-20 \\
\hline DNA Replication & 21 & 4.34E-19 \\
\hline \multicolumn{3}{|c|}{ DP2_up-regulated (in Hdac3 KO) } \\
\hline Category & Gene \# & adjp \\
\hline TCR signaling pathway & 15 & $6.31 \mathrm{E}-7$ \\
\hline Leukocyte transendothelial migration & 15 & $1.04 \mathrm{E}-6$ \\
\hline Regulation of actin cytoskeleton & 19 & $4.48 \mathrm{E}-6$ \\
\hline Jak-STAT signaling pathway & 15 & $1.34 \mathrm{E}-5$ \\
\hline MAPK signaling pathway & 20 & $1.9 \mathrm{E}-5$ \\
\hline \multicolumn{3}{|c|}{ DP2_down-regulated (in Hdac3 KO) } \\
\hline Category & Gene \# & $\operatorname{adjp}$ \\
\hline Cell Cycle & 14 & $6.8 \mathrm{E}-8$ \\
\hline Protein processing in ER & 11 & 0.0002 \\
\hline Pathways in cancer & 14 & 0.0009 \\
\hline
\end{tabular}

B
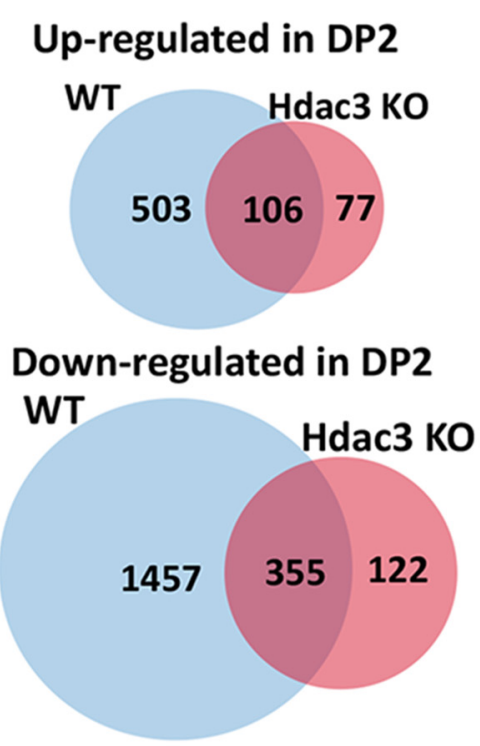

D

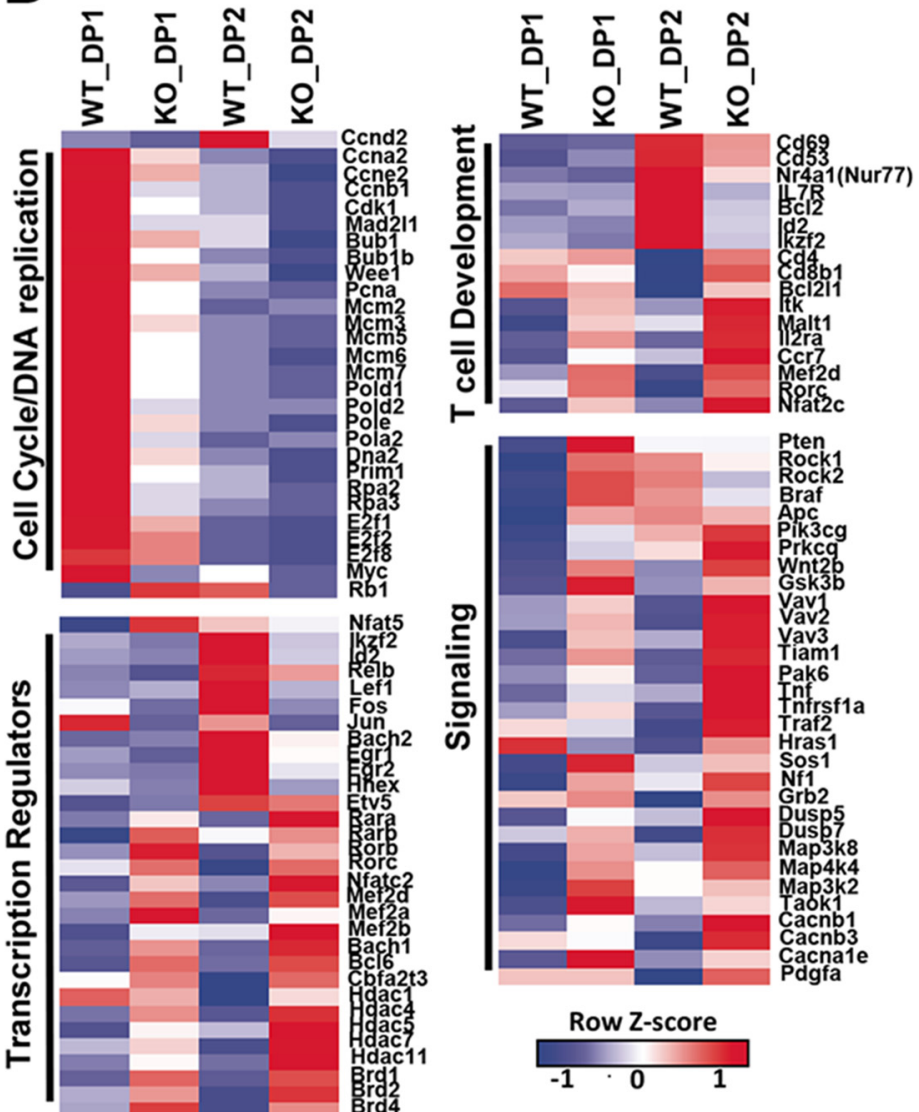

FIG 5 RNA-Seq analysis of DP1 and DP2 thymocytes. (A) The heat map depicts the changes in gene expression between WT and Hdac3 ${ }^{-1-}$ DP1 or DP2 thymocytes that were FACS prior to RNA-Seq analysis. (B) Venn diagrams show the number of genes that were upregulated or downregulated between control DP1 and DP2 cells (blue) and then the number of genes whose expression changed upon deletion of Hdac3 (pink). (C) KEGG analysis of genes dysregulated in $\mathrm{Hdac}^{-I-}$ DP1 and DP2 thymocytes. MAPK, mitogen-activated protein kinase; ER, endoplasmic reticulum. (D) Heat maps of four groups of genes from the KEGG analysis in panel C. $P$ values were calculated using a hypergeometric test (raw $P$ value) and adjusted by multiple testing (adjusted $P$ values). 

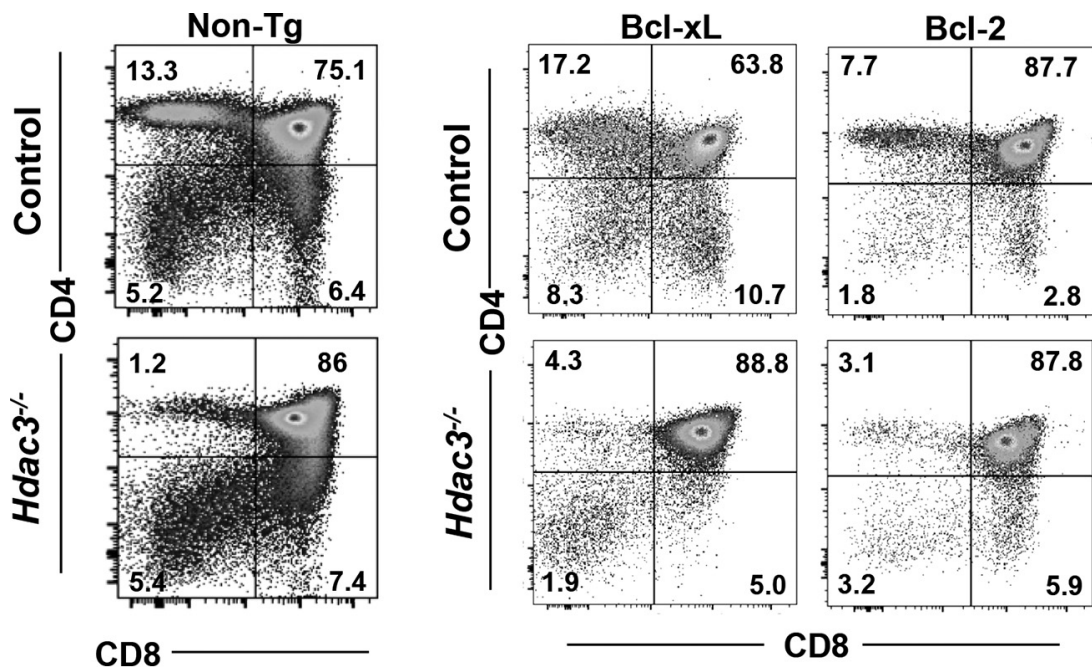

FIG 6 Transgenic mouse expression of $B c l-x L$ and $B c l 2$ does not fully complement the Hdac ${ }^{-1-}$ thymocyte defect. FACS analysis of CD4 versus CD8 cells in nontransgenic control mice (Non- $\mathrm{Tg}$ ) and $\mathrm{Hdac}^{-1-}$ mice versus mice expressing the indicated transgenes. Plots are representative of those from analyses of at least 5 mice.

gested that the $\mathrm{Hdac}^{-1-}$ thymocytes did not convert the TCR signals into robust activation of many of the genes typically activated during positive selection (e.g., Nur77, -2.0-fold; Nor1, -4.5-fold [47]; Myc, -2.7-fold), and many genes that should have been silenced were not (Fig. 5A). Therefore, we tested whether the combined effect of these changes in gene expression that suppressed metabolism and the cell cycle in the Hdac3 ${ }^{-1-}$ thymocytes (Fig. 5) could be rescued by the expression of a functional, recombined TCR $\beta$ to provide a stronger signal. We crossed our $L c k-H d a c 3^{-1-}$ mice with mice expressing a TCRß (TCRBbeta8.2) transgene (54), and FACS analysis of $L c k-H{d a c 3^{-1}}^{-1}$ TCR $\beta$ mice showed a moderate rescue of $\mathrm{CD}^{+}$cells, with $L c k$ $\mathrm{Hdac}^{-1-}$ /TCR $\beta$ mice having about twice as many $\mathrm{CD} 4^{+}$cells as

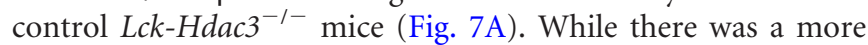
robust rescue of $\mathrm{CD} 8$ single-positive cells, this analysis was skewed by the presence of immature single-positive cells (Fig. 7A).

Given the encouraging yet incomplete rescue of CD4 selection with overexpression of a functional TCR $\beta$ receptor, we crossed our Lck-Hdac3 mice to mice expressing a fully recombined TCR $\alpha \beta$ receptor that would select through MHC class II (OT-II) to drive the production of $\mathrm{CD}^{+}{ }^{+}$cells (55). Mice with OT-II/ $\mathrm{Hdac}^{+/+}$-expressing thymocytes showed the expected increased selection for $\mathrm{CD}^{+}$cells, and mice with OT-II/Hdac3 ${ }^{-/-}$-expressing thymocytes showed a recovery of $\mathrm{CD}^{+}$cells to control levels (Fig. 7A). However, while the OT-II transgene nearly eliminated CD8 single-positive cells in the control mice, it did not resolve the accumulation of immature CD8 single-positive cells in the $L c k$ $\mathrm{Hdac}^{-/-}$mice. Nevertheless, it did drive high levels of CD5 expression in the double-positive cells (Fig. 7B), indicating a more robust level of complementation during positive selection.

\section{DISCUSSION}

The class 1 histone deacetylases (HDAC1, -2, and -3) are therapeutic targets in cutaneous T cell lymphoma (CTCL). Hdac3 is a key target for the FDA-approved drugs, and deletion of Hdac3 in hematopoietic stem cells causes a dramatic loss of lymphopoiesis due to the loss of the first multipotent lymphoid progenitor cell (23). Therefore, we used Lck-Cre-mediated deletion to define the requirements for $H d a c 3$ after cells commit to the $\mathrm{T}$ cell lineage in the double-negative stages. Hdac3 was required for T cell development from double-negative stage 4 into the early CD4/CD8 double-positive stages, with few single positive cells making it through positive selection (Fig. 1, 2, and 4). Similar results were obtained using a CD2-Cre transgene (R. Philips and V. M. Shapiro, unpublished data), further supporting a role for Hdac3 during positive selection.

In vitro, in both fibroblasts and hematopoietic stem cells, $H d a c 3$ was required for efficient proliferation due to defects in DNA replication, which triggered apoptosis $(21,23,56)$. Consistent with these findings, histone acetylation marks that are found during the deposition of histones onto newly synthesized DNA were upregulated in Hdac3-null DP thymocytes (Fig. 1). While inhibition of apoptosis by expression of $B c l-x L$ or $B c l 2$ did impact the $H d a c 3^{-1-}$ phenotype to some degree, it did not completely complement the $\mathrm{Hdac}^{-1-}$ defect and allow selection (Fig. 5). Gene expression analysis showed that nearly 2 -fold more genes were downregulated as were induced by the inactivation of $\mathrm{Hdac} 3$, but this may be due to compensation for the induction of key tumor suppressor genes (e.g., $N f 1, A p c, R b 1$ ) that impair cell cycle progression. In addition, during the DP1-to-DP2 transition there is a general loss of metabolic robustness that is also associated with a dramatic downregulation of gene expression ( 1,812 genes were downregulated, whereas 609 were upregulated) (Fig. 5B). Therefore, the disparity between the number of genes induced versus the number of genes suppressed by the inactivation of Hdac3 may be due to the stage of thymocyte differentiation being assessed. Nevertheless, the OT-II transgene, which may provide a stronger proliferative signal and support metabolic robustness, yielded a more efficient complementation of $H d a c 3$ deletion.

Changes in gene expression pinpointed defects in the expression of key regulatory genes, including many cell cycle control genes (e.g., E2F family members) (Fig. 3 and 5). Indeed, the majority of genes deregulated were expressed at significantly lower levels in the absence of $\mathrm{Hdac} 3$. Given that Hdac3 has primarily been linked to repression, the loss of expression of the majority of 


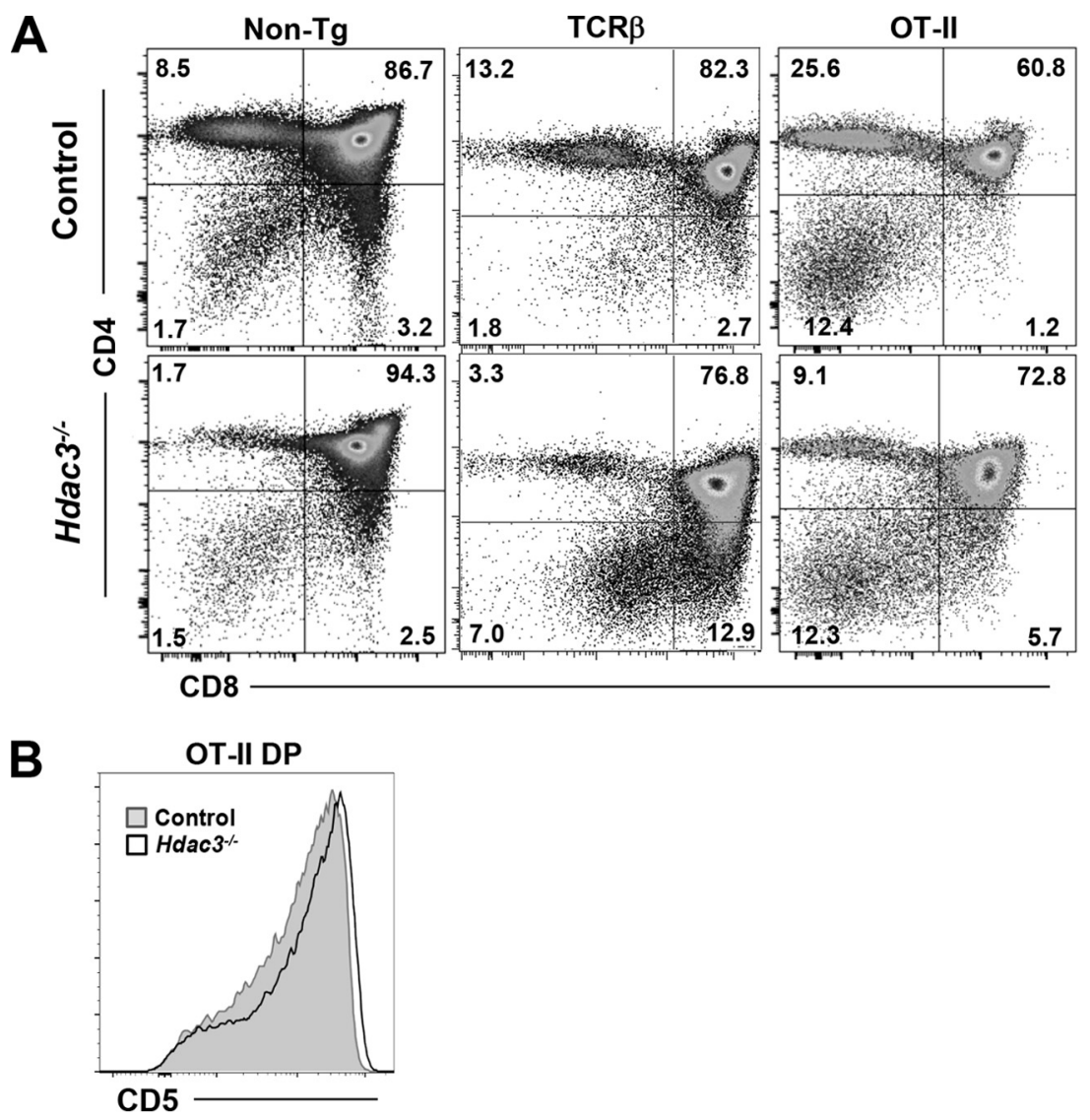

FIG 7 A TCR $\alpha \beta$ transgene complements the $H d a c 3^{-/-}$defect in thymocyte development. (A) FACS analysis of CD4 versus CD8 cells in nontransgenic control mice (Non- Tg) and Hdac $3^{-1-}$ mice versus mice expressing the indicated transgenes. (B) The defect in CD5 expression in Hdac $3^{-1-}$ mice is largely corrected by the TCR $\alpha \beta$ transgene. Plots are representative of those from analyses of at least 5 mice.

genes deregulated might be due to the impairment of thymocyte maturation at a stage where cells are less metabolically active. In fact, low levels of $M y c$ expression were found in the double-positive small cell stage of $\mathrm{T}$ cell development, where the cells are less active metabolically (35), and we observed a dramatic downregulation of metabolic genes in wild-type cells moving from DP1 to DP2 (Fig. 5A and B). In many ways, the $\mathrm{Hdac}^{-1-}$ DP1 cells had a gene expression signature more akin to that of DP2 cells, yet even within the DP2 subsets, the $\mathrm{Hdac}^{-1-}$ cells showed a greater loss of expression of cell cycle control genes (e.g., further loss of cyclin D2, cyclin A2, cyclin E2, and CDK1) (Fig. 5B and C). This could be due to the firing of cell cycle checkpoints associated with defects in histone deacetylation during the $\mathrm{S}$ phase, which is consistent with increased amounts of H4K5ac, H4K12ac, and H4K16ac (Fig. 1C).

Genetically, we were able to complement the $\mathrm{Hdac}^{-1-}$ phenotype to some extent by expressing a TCR $\beta$ transgene and to a greater degree by expressing the OT-II transgene, which contains a rearranged TCR $\alpha \beta$. In this context, roughly $9 \%$ of the null DP cells progressed to the $\mathrm{CD} 4^{+}$stage, which is similar to the findings for wild-type mice but less than the proportion for control mice expressing OT-II (Fig. 7). These results suggest the loss of transcriptional control in response to TCR signaling (Fig. 5A). Mechanistically, the apparently impaired TCR signaling could be due to upregulation of the dual-specificity phosphatase Dusp5, which dampens ERK signaling and which was linked to decreased signal- ing in muscle treated with Hdac inhibitors (39). However, while the mRNA was upregulated as much as 3.5 -fold, the increase in the steady-state level of the Dusp5 protein was modest. Therefore, this may be a broader defect in cell metabolism and gene regulation which can be bypassed by strong TCR signaling. A key component in this process is likely $M y c$ (whose expression was downregulated 2.7-fold in $\mathrm{Hdac}^{-1-}$ DP1 cells), which is a critical target of TCR signaling, and the fine-tuning of Myc levels is critical for T cell functions (57). In addition, the level of expression of GSK3 $\beta$ was also higher in $\mathrm{Hdac}^{-/-}$DP1 cells, and it phosphorylates $\mathrm{Myc}$ to control its stability in $\mathrm{T}$ cells (57). The combination of these effects was suppression of metabolic pathways activated by Myc (e.g., ribosomes; Fig. 5C), which was the most significantly associated change in gene expression and may ultimately underlie the observed defect in positive selection.

\section{ACKNOWLEDGMENTS}

We thank all the members of the S. W. Hiebert lab for helpful discussions, reagents, and advice. We thank the Vanderbilt Cell Imaging, Translational Pathology, Flow Cytometry, and Vantage Shared Resources for services and support.

This work was supported by the T. J. Martell Foundation, the Robert J. Kleberg, Jr., and Helen C. Kleberg Foundation, and National Institutes of Health grants (RO1-CA109355, RO1-CA164605 and R01-CA64140 to S.W.H.; R01-AI061721 to S.J.), and core services were performed through 
a Vanderbilt digestive disease research grant (NIDDK P30DK58404) and a Vanderbilt-Ingram Cancer Center support grant (NCI P30CA68485). A.R.S. was supported by a fellowship from the NIH (5F32HL090259), K.R.S. was supported by grant 5 T32 CA009582-26 from the NCI and a postdoctoral fellowship (PF-13-303-01-DMC) from the American Cancer Society, and L.E.G. was supported by training grant HL069765. The project described was also supported by the National Center for Research Resources (grant UL1 RR024975-01) and is now supported by the National Center for Advancing Translational Sciences (grant 2 UL1 TR000445-06).

The content is solely the responsibility of the authors and does not necessarily represent the official views of the NIH.

We declare that no conflict of interest exists.

\section{REFERENCES}

1. Seto E, Yoshida M. 2014. Erasers of histone acetylation: the histone deacetylase enzymes. Cold Spring Harb Perspect Biol 6:a018713. http://dx .doi.org/10.1101/cshperspect.a018713.

2. Hassig CA, Fleischer TC, Billin AN, Schreiber SL, Ayer DE. 1997. Histone deacetylase activity is required for full transcriptional repression by $\mathrm{mSin} 3 \mathrm{~A}$. Cell 89:341-347. http://dx.doi.org/10.1016/S0092-8674(00)80214-7.

3. Laherty CD, Yang WM, Sun JM, Davie JR, Seto E, Eisenman RN. 1997. Histone deacetylases associated with the mSin3 corepressor mediate mad transcriptional repression. Cell 89:349-356. http://dx.doi.org/10.1016 /S0092-8674(00)80215-9.

4. Li H, Leo C, Schroen DJ, Chen JD. 1997. Characterization of receptor interaction and transcriptional repression by the corepressor SMRT. Mol Endocrinol 11:2025-2037. http://dx.doi.org/10.1210/mend.11.13.0028.

5. Yang WM, Yao YL, Sun JM, Davie JR, Seto E. 1997. Isolation and characterization of cDNAs corresponding to an additional member of the human histone deacetylase gene family. J Biol Chem 272:28001-28007. http://dx.doi.org/10.1074/jbc.272.44.28001.

6. Watson PJ, Fairall L, Santos GM, Schwabe JW. 2012. Structure of HDAC3 bound to co-repressor and inositol tetraphosphate. Nature 481: 335-340. http://dx.doi.org/10.1038/nature10728.

7. Millard CJ, Watson PJ, Celardo I, Gordiyenko Y, Cowley SM, Robinson CV, Fairall L, Schwabe JW. 2013. Class I HDACs share a common mechanism of regulation by inositol phosphates. Mol Cell 51:57-67. http: //dx.doi.org/10.1016/j.molcel.2013.05.020.

8. Grozinger CM, Hassig CA, Schreiber SL. 1999. Three proteins define a class of human histone deacetylases related to yeast Hdalp. Proc Natl Acad Sci U S A 96:4868-4873. http://dx.doi.org/10.1073/pnas.96.9.4868.

9. Fischle W, Dequiedt F, Hendzel MJ, Guenther MG, Lazar MA, Voelter W, Verdin E. 2002. Enzymatic activity associated with class II HDACs is dependent on a multiprotein complex containing HDAC3 and SMRT/N-CoR. Mol Cell 9:45-57. http://dx.doi.org/10.1016/S1097 -2765(01)00429-4.

10. Petrie K, Guidez F, Howell L, Healy L, Waxman S, Greaves M, Zelent A. 2003. The histone deacetylase 9 gene encodes multiple protein isoforms. J Biol Chem 278:16059-16072. http://dx.doi.org/10 .1074/jbc.M212935200.

11. Chang HC, Guarente L. 2014. SIRT1 and other sirtuins in metabolism. Trends Endocrinol Metab 25:138-145. http://dx.doi.org/10.1016/j.tem .2013.12.001.

12. Fiorino E, Giudici M, Ferrari A, Mitro N, Caruso D, De Fabiani E, Crestani M. 2014. The sirtuin class of histone deacetylases: regulation and roles in lipid metabolism. IUBMB Life 66:89-99. http://dx.doi.org/10 .1002/iub. 1246 .

13. Roth M, Chen WY. 2014. Sorting out functions of sirtuins in cancer. Oncogene 33:1609-1620. http://dx.doi.org/10.1038/onc.2013.120.

14. Gao L, Cueto MA, Asselbergs F, Atadja P. 2002. Cloning and functional characterization of HDAC11, a novel member of the human histone deacetylase family. J Biol Chem 277:25748-25755. http://dx.doi.org/10 .1074/jbc.M111871200.

15. Villagra A, Cheng F, Wang HW, Suarez I, Glozak M, Maurin M, Nguyen D, Wright KL, Atadja PW, Bhalla K, Pinilla-Ibarz J, Seto E, Sotomayor EM. 2009. The histone deacetylase HDAC11 regulates the expression of interleukin 10 and immune tolerance. Nat Immunol 10:92100. http://dx.doi.org/10.1038/ni.1673.

16. Stengel KR, Hiebert SW. 2014. Class I HDACs affect DNA replication, repair, and chromatin structure: implications for cancer therapy. Antioxid Redox Signal 23:51-65. http://dx.doi.org/10.1089/ars.2014.5915.

17. Wells CE, Bhaskara S, Stengel KR, Zhao Y, Sirbu B, Chagot B, Cortez D, Khabele D, Chazin WJ, Cooper A, Jacques V, Rusche J, Eischen CM, McGirt LY, Hiebert SW. 2013. Inhibition of histone deacetylase 3 causes replication stress in cutaneous T cell lymphoma. PLoS One 8:e68915. http: //dx.doi.org/10.1371/journal.pone.0068915.

18. Montgomery RL, Davis CA, Potthoff MJ, Haberland M, Fielitz J, Qi X, Hill JA, Richardson JA, Olson EN. 2007. Histone deacetylases 1 and 2 redundantly regulate cardiac morphogenesis, growth, and contractility. Genes Dev 21:1790-1802. http://dx.doi.org/10.1101/gad.1563807.

19. Wilting RH, Yanover E, Heideman MR, Jacobs H, Horner J, van der Torre J, DePinho RA, Dannenberg JH. 2010. Overlapping functions of $\mathrm{Hdac} 1$ and Hdac2 in cell cycle regulation and haematopoiesis. EMBO J 29:2586-2597. http://dx.doi.org/10.1038/emboj.2010.136.

20. Yamaguchi T, Cubizolles F, Zhang Y, Reichert N, Kohler H, Seiser C, Matthias P. 2010. Histone deacetylases 1 and 2 act in concert to promote the $\mathrm{G}_{1}$-to-S progression. Genes Dev 24:455-469. http://dx.doi.org/10 $.1101 /$ gad.552310.

21. Bhaskara S, Chyla BJ, Amann JM, Knutson SK, Cortez D, Sun ZW, Hiebert SW. 2008. Deletion of histone deacetylase 3 reveals critical roles in S phase progression and DNA damage control. Mol Cell 30:61-72. http: //dx.doi.org/10.1016/j.molcel.2008.02.030.

22. Montgomery RL, Potthoff MJ, Haberland M, Qi X, Matsuzaki S, Humphries KM, Richardson JA, Bassel-Duby R, Olson EN. 2008. Maintenance of cardiac energy metabolism by histone deacetylase 3 in mice. J Clin Invest 118:3588-3597. http://dx.doi.org/10.1172/JCI35847.

23. Summers AR, Fischer MA, Stengel KR, Zhao Y, Kaiser JF, Wells CE, Hunt A, Bhaskara S, Luzwick JW, Sampathi S, Chen X, Thompson MA, Cortez D, Hiebert SW. 2013. HDAC3 is essential for DNA replication in hematopoietic progenitor cells. J Clin Invest 123:3112-3123. http://dx.doi .org/10.1172/JCI60806.

24. Bishton MJ, Harrison SJ, Martin BP, McLaughlin N, James C, Josefsson EC, Henley KJ, Kile BT, Prince HM, Johnstone RW. 2011. Deciphering the molecular and biologic processes that mediate histone deacetylase inhibitor-induced thrombocytopenia. Blood 117:3658-3668. http://dx.doi .org/10.1182/blood-2010-11-318055.

25. Heideman MR, Wilting RH, Yanover E, Velds A, de Jong J, Kerkhoven RM, Jacobs H, Wessels LF, Dannenberg JH. 2013. Dosage-dependent tumor suppression by histone deacetylases 1 and 2 through regulation of c-Myc collaborating genes and p53 function. Blood 121:2038-2050. http: //dx.doi.org/10.1182/blood-2012-08-450916.

26. Santoro F, Botrugno OA, Dal Zuffo R, Pallavicini I, Matthews GM, Cluse L, Barozzi I, Senese S, Fornasari L, Moretti S, Altucci L, Pelicci PG, Chiocca S, Johnstone RW, Minucci S. 2013. A dual role for Hdacl: oncosuppressor in tumorigenesis, oncogene in tumor maintenance. Blood 121:3459-3468. http://dx.doi.org/10.1182/blood-2012-10-461988.

27. Trapnell C, Roberts A, Goff L, Pertea G, Kim D, Kelley DR, Pimentel H, Salzberg SL, Rinn JL, Pachter L. 2012. Differential gene and transcript expression analysis of RNA-seq experiments with TopHat and Cufflinks. Nat Protoc 7:562-578. http://dx.doi.org/10.1038/nprot.2012.016.

28. Mao X, Fujiwara Y, Chapdelaine A, Yang H, Orkin SH. 2001. Activation of EGFP expression by Cre-mediated excision in a new ROSA26 reporter mouse strain. Blood 97:324-326. http://dx.doi.org/10.1182/blood.V97.1 .324 .

29. Thapa P, Das J, McWilliams D, Shapiro M, Sundsbak R, Nelson-Holte M, Tangen S, Anderson J, Desiderio S, Hiebert S, Sant'angelo DB, Shapiro VS. 2013. The transcriptional repressor NKAP is required for the development of iNKT cells. Nat Commun 4:1582. http://dx.doi.org/10 $.1038 /$ ncomms 2580 .

30. Allen JM, Forbush KA, Perlmutter RM. 1992. Functional dissection of the lck proximal promoter. Mol Cell Biol 12:2758-2768.

31. Godfrey DI, Kennedy J, Suda T, Zlotnik A. 1993. A developmental pathway involving four phenotypically and functionally distinct subsets of $\mathrm{CD}^{-} \mathrm{CD}^{-} \mathrm{CD}^{-}$triple-negative adult mouse thymocytes defined by CD44 and CD25 expression. J Immunol 150:4244-4252.

32. Godfrey DI, Kennedy J, Mombaerts P, Tonegawa S, Zlotnik A. 1994. Onset of TCR-beta gene rearrangement and role of TCR-beta expression during $\mathrm{CD}^{-} \mathrm{CD}^{-} \mathrm{CD}^{-}$thymocyte differentiation. J Immunol 152: 4783-4792.

33. Zeng L, Dalheimer SL, Yankee TM. 2007. Gads ${ }^{-1-}$ mice reveal functionally distinct subsets of $\mathrm{TCR}^{-}{ }^{+} \mathrm{CD} 4^{-} \mathrm{CD}^{-}$double-negative 
thymocytes. J Immunol 179:1013-1021. http://dx.doi.org/10.4049/jimmunol .179 .2 .1013 .

34. Xiong J, Armato MA, Yankee TM. 2011. Immature single-positive CD8 ${ }^{+}$ thymocytes represent the transition from Notch-dependent to Notchindependent T-cell development. Int Immunol 23:55-64. http://dx.doi .org/10.1093/intimm/dxq457.

35. Mingueneau M, Kreslavsky T, Gray D, Heng T, Cruse R, Ericson J, Bendall S, Spitzer MH, Nolan GP, Kobayashi K, von Boehmer H, Mathis D, Benoist C, Best AJ, Knell J, Goldrath A, Jojic V, Koller D, Shay T, Regev A, Cohen N, Brennan P, Brenner M, Kim F, Rao TN, Wagers A, Heng T, Ericson J, Rothamel K, Ortiz-Lopez A, Mathis D, Benoist C, Bezman NA, Sun JC, Min-Oo G, Kim CC, Lanier LL, Miller J, Brown B, Merad M, Gautier EL, Jakubzick C, Randolph GJ, Monach P, Blair DA, Dustin ML, Shinton SA, Hardy RR, Laidlaw D, Collins J, et al. 2013. The transcriptional landscape of alphabeta $\mathrm{T}$ cell differentiation. Nat Immunol 14:619-632. http://dx.doi.org/10.1038/ni.2590.

36. Wang R, Xie H, Huang Z, Ma J, Fang X, Ding Y, Sun Z. 2011. Transcription factor network regulating $\mathrm{CD}(+) \mathrm{CD} 8(+)$ thymocyte survival. Crit Rev Immunol 31:447-458. http://dx.doi.org/10.1615 /CritRevImmunol.v31.i6.10.

37. Sudo T, Nishikawa S, Ohno N, Akiyama N, Tamakoshi M, Yoshida H, Nishikawa S. 1993. Expression and function of the interleukin 7 receptor in murine lymphocytes. Proc Natl Acad Sci U S A 90:9125-9129. http://dx .doi.org/10.1073/pnas.90.19.9125.

38. Trigueros C, Hozumi K, Silva-Santos B, Bruno L, Hayday AC, Owen MJ, Pennington DJ. 2003. Pre-TCR signaling regulates IL-7 receptor alpha expression promoting thymocyte survival at the transition from the double-negative to double-positive stage. Eur J Immunol 33:1968-1977. http://dx.doi.org/10.1002/eji.200323831.

39. Ferguson BS, Harrison BC, Jeong MY, Reid BG, Wempe MF, Wagner FF, Holson EB, McKinsey TA. 2013. Signal-dependent repression of DUSP5 by class I HDACs controls nuclear ERK activity and cardiomyocyte hypertrophy. Proc Natl Acad Sci U S A 110:9806-9811. http://dx.doi .org/10.1073/pnas.1301509110.

40. Tarakhovsky A, Kanner SB, Hombach J, Ledbetter JA, Muller W, Killeen N, Rajewsky K. 1995. A role for CD5 in TCR-mediated signal transduction and thymocyte selection. Science 269:535-537. http://dx.doi .org/10.1126/science.7542801.

41. Yang Y, Contag CH, Felsher D, Shachaf CM, Cao Y, Herzenberg LA, Herzenberg LA, Tung JW. 2004. The E47 transcription factor negatively regulates CD5 expression during thymocyte development. Proc Natl Acad Sci U S A 101:3898-3902. http://dx.doi.org/10.1073/pnas.0308764101.

42. Yamashita I, Nagata T, Tada T, Nakayama T. 1993. CD69 cell surface expression identifies developing thymocytes which audition for $\mathrm{T}$ cell antigen receptor-mediated positive selection. Int Immunol 5:1139-1150. http://dx.doi.org/10.1093/intimm/5.9.1139.

43. Weinreich MA, Hogquist KA. 2008. Thymic emigration: when and how T cells leave home. J Immunol 181:2265-2270. http://dx.doi.org/10.4049 /jimmunol.181.4.2265.

44. Murray R, Suda T, Wrighton N, Lee F, Zlotnik A. 1989. IL-7 is a growth and maintenance factor for mature and immature thymocyte subsets. Int Immunol 1:526-531. http://dx.doi.org/10.1093/intimm/1.5.526.

45. Linette GP, Grusby MJ, Hedrick SM, Hansen TH, Glimcher LH,
Korsmeyer SJ. 1994. Bcl-2 is upregulated at the $\mathrm{CD} 4^{+} \mathrm{CD} 8^{+}$stage during positive selection and promotes thymocyte differentiation at several control points. Immunity 1:197-205. http://dx.doi.org/10.1016 /1074-7613(94)90098-1.

46. Sun Z, Unutmaz D, Zou YR, Sunshine MJ, Pierani A, Brenner-Morton S, Mebius RE, Littman DR. 2000. Requirement for RORgamma in thymocyte survival and lymphoid organ development. Science 288:23692373. http://dx.doi.org/10.1126/science.288.5475.2369.

47. Cheng LE, Chan FK, Cado D, Winoto A. 1997. Functional redundancy of the Nur77 and Nor-1 orphan steroid receptors in T-cell apoptosis. EMBO J 16:1865-1875. http://dx.doi.org/10.1093/emboj/16.8.1865.

48. Ci W, Polo JM, Cerchietti L, Shaknovich R, Wang L, Yang SN, Ye K, Farinha P, Horsman DE, Gascoyne RD, Elemento O, Melnick A. 2009. The BCL6 transcriptional program features repression of multiple oncogenes in primary B cells and is deregulated in DLBCL. Blood 113:55365548. http://dx.doi.org/10.1182/blood-2008-12-193037.

49. Fujiwara T, Lee HY, Sanalkumar R, Bresnick EH. 2010. Building multifunctionality into a complex containing master regulators of hematopoiesis. Proc Natl Acad Sci U S A 107:20429-20434. http://dx.doi .org/10.1073/pnas.1007804107.

50. Chao DT, Linette GP, Boise LH, White LS, Thompson CB, Korsmeyer SJ. 1995. Bcl-XL and Bcl-2 repress a common pathway of cell death. J Exp Med 182:821-828. http://dx.doi.org/10.1084/jem.182.3.821.

51. Linette GP, Hess JL, Sentman CL, Korsmeyer SJ. 1995. Peripheral T-cell lymphoma in lckpr-bcl-2 transgenic mice. Blood 86:1255-1260.

52. He TC, Sparks AB, Rago C, Hermeking H, Zawel L, da Costa LT, Morin PJ, Vogelstein B, Kinzler KW. 1998. Identification of c-MYC as a target of the APC pathway. Science 281:1509-1512. http://dx.doi.org/10.1126 /science.281.5382.1509.

53. van Riggelen J, Yetil A, Felsher DW. 2010. MYC as a regulator of ribosome biogenesis and protein synthesis. Nat Rev Cancer 10:301-309. http://dx.doi.org/10.1038/nrc2819.

54. Uematsu Y, Ryser S, Dembic Z, Borgulya P, Krimpenfort P, Berns A, von Boehmer H, Steinmetz M. 1988. In transgenic mice the introduced functional $\mathrm{T}$ cell receptor beta gene prevents expression of endogenous beta genes. Cell 52:831-841. http://dx.doi.org/10.1016/0092 -8674(88)90425-4.

55. Barnden MJ, Allison J, Heath WR, Carbone FR. 1998. Defective TCR expression in transgenic mice constructed using cDNA-based alpha- and beta-chain genes under the control of heterologous regulatory elements. Immunol Cell Biol 76:34-40. http://dx.doi.org/10.1046/j.1440-1711 .1998.00709.x.

56. Bhaskara S, Knutson SK, Jiang G, Chandrasekharan MB, Wilson AJ, Zheng S, Yenamandra A, Locke K, Yuan JL, Bonine-Summers AR, Wells CE, Kaiser JF, Washington MK, Zhao Z, Wagner FF, Sun ZW, Xia F, Holson EB, Khabele D, Hiebert SW. 2010. Hdac3 is essential for the maintenance of chromatin structure and genome stability. Cancer Cell 18:436-447. http://dx.doi.org/10.1016/j.ccr.2010.10.022.

57. Preston GC, Sinclair LV, Kaskar A, Hukelmann JL, Navarro MN, Ferrero I, MacDonald HR, Cowling VH, Cantrell DA. 2015. Single cell tuning of Myc expression by antigen receptor signal strength and interleukin-2 in T lymphocytes. EMBO J 34:2008-2024. http://dx.doi.org/10 $.15252 / \mathrm{embj} .201490252$. 